ISSN 2201-2796

\title{
NIGERIAN'S NASCENT SECONDARY SCHOOL PHYSICS CURRICULUM AND ITS IMPLEMENTATION PROBLEMS
}

\author{
NWOYE, AMARACHUKWU NKECHI \\ SCIENCE EDUCATION DEPARTMENT \\ NNAMDI AZIKIWE UNIVERSITY \\ AWKA, NIGERIA \\ an.nwoye@unizik.edu.ng \\ OKAFOR, ANTHONY. E \\ SCIENCE EDUCATION DEPARTMENT \\ NNAMDI AZIKIWE UNIVERSITY \\ AWKA, NIGERIA \\ okafortonye@gmail.com
}

DOI: 10.31364/SCIRJ/v7.i6.2019.P0619666

http://dx.doi.org/10.31364/SCIRJ/v7.i6.2019.P0619666

\begin{abstract}
Due to the sharp declination of students' academic performance in 2014 and 2015, the researchers deemed it necessary to investigate on Nigerian's nascent secondary school physics curriculum and its implementation problems. Four research questions guided the study. The study adopted a descriptive survey design. The research was carried out in Otuocha education zone, Anambra State. The sample constituted of 465 respondents. Teachers Students Assessment Questionnaire (TSAQ) was used for data collection. The data collected were analysed using frequency and mean. Findings showed that; government, environmental among others related problems impede the implementation of the new curriculum. Based on the findings, it was recommended that university courses in science education should also inculcate the secondary school curriculum content among others.
\end{abstract}

\section{Key words: Physics Education, Curriculum, Implementation and Academic Performance}

\section{INTRODUCTION}

Nigerian government in its responsiveness to the aged long problems in education sector and to ensure the actualization of the past administration's seven point agenda embarked on curriculum reform process in 2008. Nigeria Educational Research and Development Council (NERDC) with the few stakeholders in education saddled with the responsibilities of designing, reviewing and planning the nation's education curriculum came up with the nascent curriculum. This document has enjoyed a lot of accolades from professional in the field of education. Unachukwu (2009) affirms that for school learning to be meaningful, there is the need for constant change of school curriculum. In a similar view, Agbionu (2010) maintained that curriculum should be a dependent variable, changing with the needs of the learner. To buttress the fact, if a given curriculum is used for learner A to solve his learning need $\mathrm{X}$, that the same curriculum cannot be used for the same learner to solve his learning need $\mathrm{Y}$, otherwise the curriculum will be addressing wrong learning need. Nevertheless, the new curriculum is a reflection of patch work of many thoughts and marriage of many practices brought together by the very best brains of the country in education mustered at that point in time. It was planned that the products of the new curriculum will proceed to senior secondary in 2011 and probably graduating in 2014 academic session barely two years ago.

The outcome of the reform ushered in a new curriculum which cuts across many disciplines including sciences (physics). New secondary school physics curriculum, as matter of facts has its structure changed shifting the paradigm from the conceptual 
ISSN 2201-2796

approach or spiral approach to the thematic approach. The new approach to the content organization has six themes unlike the previous that had five. This implies that there were inclusion of additional topics, contents and a new theme (physics in technology) to the old physics curriculum. These giant strides by NERDC were according to Obioma(2008) for the best interest of the country and to ensure compliance with the national and global issues as well as further strengthened the objectives of physics education as enshrined in the National Policy on Education(2004) without necessary overloading the content of the new document. Expressing his optimism was Adeyemo (2010) who opined that the gap on similarities and differences between physics and technology has been closed. To him, the introduction of physics in technology into the new physics curriculum is applause. Since physics contributes its quota in accelerating the development lacking in Africa and Nigeria in particular.

Suffice to say, that aims and objectives of any level of education cannot be achieved if the planned program for such level is not well implemented. Observing this, Onyeachu (2008) asserted, "no matter how well a curriculum of any subject is planned, designed and documented, implementation is important". It is at the implementation that excellent curriculum plans and other educational policies are married without any trace, Babalola (2004) and Mkpa (2005). Unfortunately, the implementation of the new curriculum especially physics have been fraught with challenges which apparently prevented students from performing well in external examinations. This invariably, showcases the ordeals teachers in the field pass through regarding the implementation. The evidence ranging from the poor performance of the recipient in 2014 WAEC (Dailypost August 11, 2014) is so glaring creating a wide disparity between the prescribed programme and its implementation.

The background information underscores the needs to unveil the problems confronting the new physics curriculum for secondary schools in Nigeria for the optimum performance of our dear children.

\section{Purpose of the Study}

The main purpose of the study is to investigate on the implementation problems of Nigerian's nascent secondary school physics curriculum in Anambra State. Specifically the study sought to ascertain;

1. Government - related problems facing the implementation of the new secondary school Physics curriculum

2. Teachers related problems facing the implementation of new secondary school physics curriculum

3. Students - related problems facing the implementation of new secondary school physics curriculum.

4. Environmental related problems facing the implementation of new secondary school physics curriculum

\section{Research Questions}

In order to make the research work successful, the following research questions were posed. What are the;

1. Governments related problems facing the implementation of the new secondary school physics curriculum?

2. Teachers' related problems facing the new secondary school physics curriculum?

3. Students' related problems facing the new secondary school physics curriculum?

4. Environmental related problems facing the new secondary school physics curriculum?

\section{METHODS}

The population from which the sample was drawn consist of Physics Teachers and Students in Secondary Schools in Otuocha Zone of Anambra State. The sample size was 465 which consist of 15 Physics Teachers and 450 Physics Students. The data for this study were collected by using structured questionnaire designed by the researchers and validated for the purpose of the study. 
ISSN 2201-2796

The questionnaire was titled Teachers Student Assessment questionnaire (TSAQ) and consisted 18 items based on research question.

To answer the research questions that guided the study, the data collected were analyzed using a Five (5) point Likert scale of Strongly Agreed (SA), Agreed (A), Undecided (UD), Disagreed (DA), and Strongly Disagreed (SD). Data were analyzed using descriptive statistics of frequency distribution and mean.

In order to take decision on the problem facing implementation of the new secondary school Physics curriculum, the researchers chose a mean cut off point of 3.00. Thus, the questionnaire item with mean score of 3.00 or above was considered as agreed while an item that scored less than 3.00 was taken as disagreed.

\section{RESULTS}

Research Question One: What are the governments related problems facing implementation of the new secondary school physics curriculum?

Table 1: Government Related Challenges Facing the New Curriculum

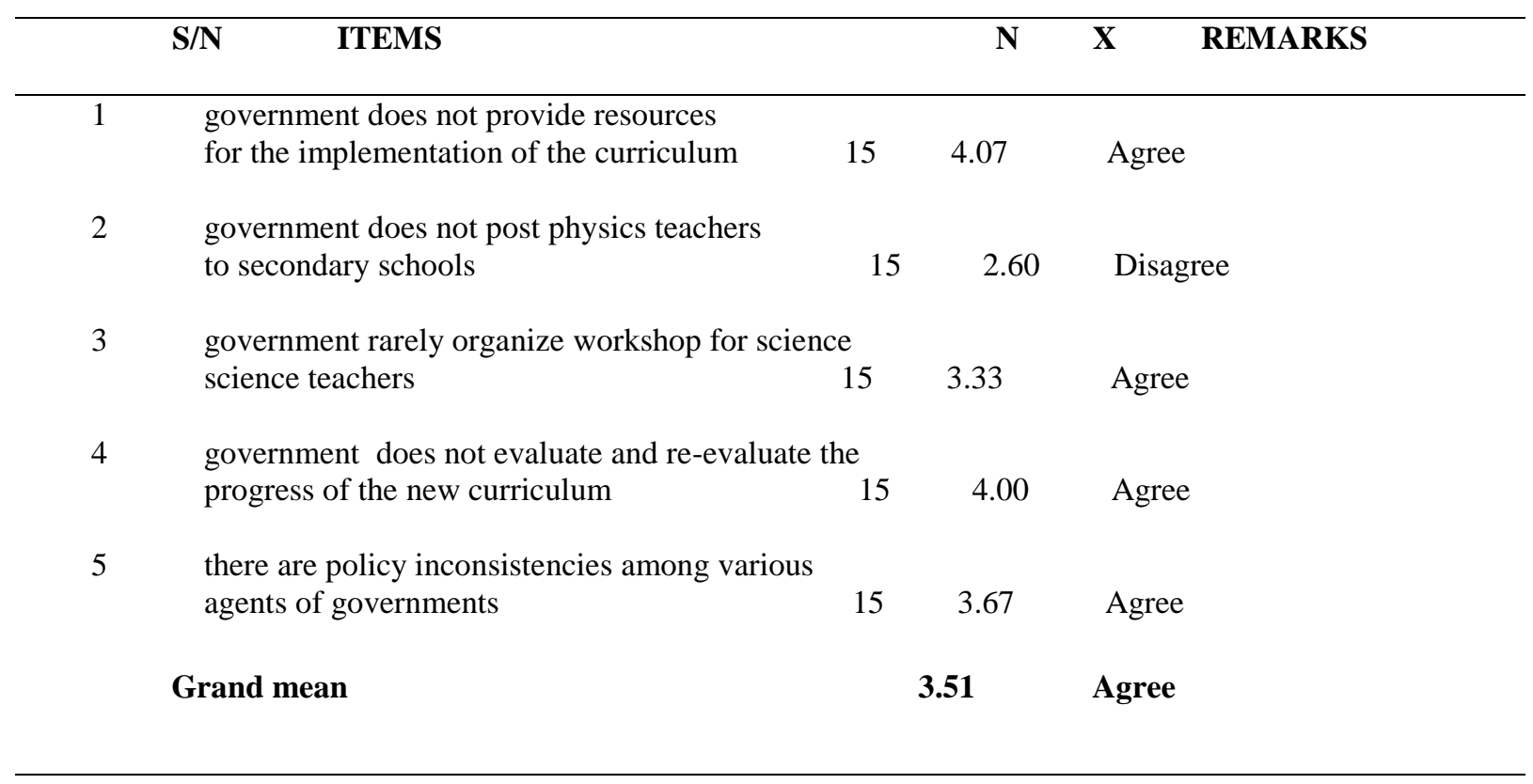

From table 1 above, item 1 has a mean score of 4.07, item 3 has 3.40 while item 4 has 4.00 and item 5 has 3.67 . The mean scores are greater than the cut-off point of 3.00 indicating that government does not provide resources for implementing the new physics curriculum, government rarely organize workshop for science teachers, government does not evaluate and re-evaluate the progress of the new physics curriculum and finally there are policy inconsistencies among various agents of governments. On the other hand, item 2 has the mean score of 2.40 which is less than the cut-off point of 3.00 and hence disagreed. Also, the mean of means computed from the table above exceeded the cut-off point of 3.00 showing that the research question 1 was accepted by the respondents.

Research Question Two: What are the teachers related problems facing the implementation of the new Physics curriculum? 
Table 2: Teachers Related Challenges Facing New Physics Curriculum

\begin{tabular}{|c|c|c|c|c|}
\hline \multirow{3}{*}{$\frac{\mathbf{S} / \mathbf{N}}{6}$} & ITEMS & & $\ddot{\mathbf{X}}$ & REMARKS \\
\hline & teachers are not knowledgeable of & & & \\
\hline & Some content of new physics curriculum & 15 & 3.47 & Agree \\
\hline 7 & physics teachers are not given incentives & 15 & 3.40 & Agree \\
\hline 8 & $\begin{array}{l}\text { time allotted to physics in the school time } \\
\text { table is inadequate }\end{array}$ & 15 & 4.07 & Agree \\
\hline 9 & $\begin{array}{l}\text { most of the physics teachers are not specialist } \\
\text { In the subject area }\end{array}$ & 15 & 3.20 & Agree \\
\hline 10 & $\begin{array}{l}\text { teachers luke-warm attitudes to posting affect } \\
\text { Teaching and learning of physics }\end{array}$ & 15 & 3.67 & Agree \\
\hline & Grand mean & & 3.53 & Agree \\
\hline
\end{tabular}

From table 2 above, items 6,7,8,9 and 10 have means scores greater than the cut-off point of 3.00. Which reveal that there are teacher's related problems affecting the successful implementation of the new Physics curriculum in secondary schools.

Research Question Three: What are the students' related problems facing the implementation of the new secondary school Physics curriculum?

Table 3: Students Related Problems Facing the New Curriculum

\begin{tabular}{rlccc}
\hline S/N & \multicolumn{1}{c}{ Items } & N & X & REMARKS \\
\hline 11 & $\begin{array}{l}\text { Textbooks in use do not address the } \\
\text { content to the new curriculum }\end{array}$ & 450 & 3.48 & Agree \\
12 & $\begin{array}{l}\text { Students poor performance in } \\
\text { mathematics affects physics teaching and learning } 450\end{array}$ & 3.56 & Agree \\
$13 \quad \begin{array}{l}\text { Parental occupation affects students } \\
\text { performance in physics }\end{array}$ & 450 & 2.63 & Disagree \\
$14 \quad \begin{array}{l}\text { Abstract nature of physics subject hinders } \\
\text { its learning }\end{array}$ & 450 & 3.55 & Agree \\
15 & $\begin{array}{l}\text { There are lack of interest among students } \\
\text { in learning physics }\end{array}$ \\
Grand mean & 450 & 3.50 & Agree \\
\hline
\end{tabular}

From table 3 above, items 11, 12, 14 and 15 were rated very high by the respondents. Having means scores greater than the cutoff point of 3.00, it is the opinion of the respondents that those items affect the successful implementation of the new secondary school Physics curriculum. Item 13 has been rejected having a mean score of 2.63 which imply that parental occupation does not in any way affects students' performance in physics. However, the mean of means from table above showed that the research question iii was accepted by the respondents and hence there are student's related problems facing the implementation of the new secondary school physics curriculum. 
ISSN 2201-2796

Research Question Four: What are the Environmental related problems facing the implementation of the new secondary school physics curriculum?

Table 4: Environmental Factors Affecting the Implementation of the New Physics Curriculum

\begin{tabular}{|c|c|c|c|c|c|}
\hline $\mathbf{S} / \mathbf{N}$ & Items & $\mathbf{N}$ & \multicolumn{2}{|c|}{ REMARKS } & \\
\hline & Learning of physics & & 450 & 3.44 & Agree \\
\hline 17 & $\begin{array}{l}\text { Poor living condition of parents affect } \\
\text { Teaching and learning of physics }\end{array}$ & & 450 & 3.41 & Agree \\
\hline 18 & $\begin{array}{l}\text { Non-availability of basics amenities } \\
\text { Affect implementation of the new physics } \\
\text { Curriculum }\end{array}$ & & 450 & 3.63 & Agree \\
\hline & Grand mean & & & 3.49 & Agree \\
\hline
\end{tabular}

From table 4 above, item 16 - 18 have means scores greater than the cutoff point. Their various mean scores are $3.44,3.41$ and 3.63 respectively. This also indicates that environmental problems affect implementation of the new secondary school curriculum.

\section{DISCUSSION}

The findings of the study from table 1 constructed based on the research question 1 revealed that government posts physics teachers to the secondary schools in Anambra State. This is in a strong agreement with the Post Primary Schools Service Commission (PPSSC) (2013), a total of 99 physics teachers were unproportionally posted across the six educational zones of the state; Aguata Zone 13, Awka Zone 29, Nnewi Zone 21, Ogidi Zone 12, Onitsha Zone 15 and Otuocha Zone 9. Looking at the number of physics teachers in school which is grossly inadequate, Otuocha education Zone has the least and conversely will have effect on the implementation of the new curriculum.

The investigation further revealed that teachers are not knowledgeable of some contents of the new curriculum. This observation is in line with Omosewo (2001) who stated that teachers that taught physics at Senior Secondary level could not teach some topics because they were not taught while in the colleges of education and universities. Also, the study showed that physics teachers are not given incentives. This assertion is supported by Ugwu (2005) who opined that when a person is gingered to do something, that person is motivated, he must in addition to his/her salaries and entitlement given an incentives. The study also found that time allotted to physics in the school time-table is not enough in consonant with Akuezuilo (1981), who lamented on the inadequate time allotted to science in school time-table.

In table 3, the study showed that textbooks in use for physics at senior secondary level do not address the content of the new physics curriculum. This view is supported by Rutherford (2005) who believed that every science discipline has stories to tell, ideas to explore, advances and disappointment to confront, applications to astound, mysteries to solved and new mysteries created, but these are not found in our science textbooks. A glaring consequence here is that knowledge construction in science is hampered because some vital procedure and information necessary are lacking. Further findings from the study showed that abstract nature of physics subject hinders its learning. This is in agreement with Adewale (2002), who noted that some concepts of the curriculum are too abstract for students to comprehend.

Finally, the finding of the study revealed in table 4 that seasonal challenges affect teaching and learning of physics. According to STAN (2009), earth is complex and influenced by many things particularly changes in the earth's orbits in relation to the sun. But even when all these factors are taken into account, the percentage reduction is minimum because they can be accounted for by natural factors. Hence, environment affects the implementation of the new physics curriculum, because they can be accounted for by natural factors. Hence, environment affects the implementation of the new physics curriculum. 
ISSN 2201-2796

\section{CONCLUSIONS}

The study was carried out to find out the problems encountered in implementation of the new secondary school physics curriculum in Otuocha education Zone of Anambra State. The findings of the study revealed that there have not been successful implementations of the new physics curriculum. Some problems have been identified to militating against the new curriculum which include; government related problems like; inadequate provision of resources, policy inconsistencies among various agents of government, etc. There also exist teacher's related problems; teacher's luke-warm attitudes to posting, the use of non-physics specialists to teach physics at secondary school level etc.

Furthermore, factors such as incoherent nature of science textbooks, students' poor foundation in mathematics, lack of interest amongst students in physics e.t.c have been identified to have constituted problems to the new physics curriculum. And lastly, the study has identified some environmental factors which included seasonal challenges e.g. flood, non-provision of basic amenities and poor living condition of parents to have adversely affected the new physics curriculum. With these evidence, it could be concluded that proper implementation of the new physics curriculum has been fraught with challenges.

\section{Recommendations}

In view of the above findings, the following recommendations are thought to be in order in other to improve the implementation process of the new physics curriculum in Anambra State.

1. University Physics students should have as a part of their course, the physics contents they are going to teach at secondary school level.

2. As a matter of urgency, seminars and workshops should be organized for physics teachers on the field before 2021 .

3. There should be availability of adequate textbooks for the students

4. Abstract or difficult contents of the new physics curriculum should be reviewed

5. Government should employ more of the physics teachers to secondary schools

6. There should be constant evaluation and reevaluation of the new physics curriculum.

\section{Suggestion for Further Research}

The following are suggested for further research.

1. To extend the scope of the study beyond Otuocha education Zone

2. Comparative assessment of the old and the new physics curriculum for secondary schools

\section{REFERENCES}

Adewale, J.O (2002).Modern Trend in Physics Teaching at Secondary School Level, Institution of Education, University of Ibadan.

Adeyemo, S.A (2010). The Curriculum Transformation: Issues Problem and Prospects. International Journal for Education Research Technology (IJERT). Vol (1), 99-111.

Agbaionu, E.O (2010). Desirable Entrepreneurship in Nigeria Economic Situation. Unizik Orient Journal of Education. Vol. (1)

Akuezuilo, E.O (1981). A Critical Appraisal of the Current Science Syllabus for Grade II Teachers' Certificate. $-26^{\text {th }}$. A Paper Presented at the Workshop on "Preparation of Primary Science Teachers" Organized by CUDIMAC, University of Nigerian Nsukka. June $25^{\text {th }} 198$ 
ISSN 2201-2796

Babalola, V.O (2004). Problems of Curriculum Planning and Implementation in the $21^{\text {st }}$ Century: Noah

Federal Republic Nigeria (2007) National Policy on Education. Lagos: NERDC Press.

Godwill, O. (2008). Appraisal of the New Secondary School Physics Curriculum. Federal Ministry of Education: Abuja

Mkpa, M.A (2005) Challenges for Implementing the School Curriculum in Nigeria: Journal for Curriculum Studies 12 (1) 9

Federal Ministry of Education (2008). The New Secondary Curriculum Structure at a Glance. Abuja, NERDC

Omosewo, E.O (2001). In-service Programme for Senior Physics Teachers for Improved Teaching and Assessment of Students. Nigerian Journal of Development Issues: Education, Socio-Political and Economic Development. 5(1\&2) 200-219.

Onyeachu, J.A.E (2008).Curriculum Implementation at the Primary Educational Levels Challenges For $21^{\text {st }}$ Century: Multidisciplinary Journal Research Development Vol(1), 38-49

Rutherford, F.J (2005). Is Our Past Our Future? Thoughts on the Next 50 Years of Science Education

Reform In The Light of Judgment on the 50 Years; Journal of Education, 14(4), 367-386

Science Teachers Association of Nigeria (2009). Bulletin, Vol.26. No.2 December, 2009. Abuja.

Unachukwu, G.C \& Ebenebe,R.C (2009). Developmental Psychology and Education. Agatha Series Publishers, Enugu. In Association with Facts (Exports) Ltd. 